\title{
Deciphering splenic marginal zone lymphoma pathogenesis: the proposed role of microRNA
}

\author{
Jacob E. Robinson ${ }^{1}$ and Christine E. Cutucache ${ }^{1}$ \\ ${ }^{1}$ Deptartment of Biology, University of Nebraska at Omaha, Omaha, NE 68182, USA \\ Correspondence to: Christine E. Cutucache, email: ccutucache@unomaha.edu \\ Keywords: splenic marginal zone lymphoma; microRNA; CAV1; caveolin-1; 7q \\ Received: December 22, $2017 \quad$ Accepted: May 09, $2018 \quad$ Published: July 06, 2018 \\ Copyright: Robinson et al. This is an open-access article distributed under the terms of the Creative Commons Attribution License \\ 3.0 (CC BY 3.0), which permits unrestricted use, distribution, and reproduction in any medium, provided the original author and \\ source are credited.
}

\section{ABSTRACT}

Splenic marginal zone lymphoma (SMZL) is a malignancy of mature B-cells that primarily involves the spleen, but can affect peripheral organs as well. Even though SMZL is overall considered an indolent malignancy, the majority of cases will eventually progress to be more aggressive. In recent years, the gene expression profile of SMZL has been characterized in an effort to identify: 1) the etiology of SMZL, 2) biological consequences of $S M Z L$, and 3) putative therapeutic targets. However, due to the vast heterogeneity of the malignancy, no conclusive target(s) have been deciphered. However, the role of miRNA in SMZL, much as it has in chronic lymphocytic leukemia, may serve as a guiding light. As a result, we review the comprehensive expression profiling in SMZL to-date, as well as describe the miRNA (and potential mechanistic roles) that may play a role in SMZL transformation, particularly within the $7 q$ region.

\section{INTRODUCTION}

Splenic marginal zone lymphoma (SMZL) is a lowgrade, mature B-cell lymphoma, primarily involving the spleen with variable progression seen in the bone marrow and peripheral blood $[1,2]$. SMZL accounts for less than $2 \%$ of all lymphoid malignancies and is responsible for less than $1 \%$ of non-Hodgkin's lymphoma cases [3-5]. SMZL is considered an indolent B-cell lymphoma as the median overall survival (OS) for SMZL cases is between 8 and 11 years, but clinical presentations remain very heterogeneous [6-8]. Most importantly, it is estimated that $70 \%$ of SMZL cases will at some point require treatment for worsening symptoms [2, 9], and approximately $30 \%$ of SMZL patients will display a more aggressive prognosis with potential for progression to more lethal lymphomas and a decreased overall survival [1, 10-14]. Due to the limited number of available cases as well as the heterogeneous nature of SMZL, it is very difficult to differentiate indolent and aggressive SMZL cases, resulting in treatment inconsistencies and discrepancies among predicted clinical prognoses. Consequently, further investigations into the biological mechanism(s) that result in SMZL development are essential for improving the diagnostic and prognostic reliability.

\section{Etiology of SMZL}

In an effort to elucidate the biological mechanisms of SMZL, research involving gene expression analyses and chromosomal aberration studies have been conducted. Specifically, SMZL presents with genomic instability in approximately $75 \%$ of cases, resulting in one of the highest percentages compared to other B-cell lymphomas, and accentuating the variable nature of the disease [15]. This variability offers potential opportunities in identifying diagnostic and subsequent treatment targets. Thus far, the most common chromosomal abnormality is a $7 \mathrm{q}$ deletion occurring in $30 \%$ to $40 \%$ of patients. The loss of $7 \mathrm{q}$ regions is seen much more frequently in SMZL compared with similar B-cell neoplasms, and thus, it has been proposed as a primary diagnostic marker [16-19]. The primary region resulting in the loss of heterozygosity $(\mathrm{LOH})$ has been identified between $7 \mathrm{q} 21$ and $7 \mathrm{q} 33$, but the precise chromosomal locations responsible, and resulting mechanisms, remain unknown [20-22]. Further, the direct 
effects of the 7q deletion on SMZL pathogenesis also remains controversial.

In addition to the deletion within the $7 \mathrm{q}$ region, there are a plethora of other cytogenetic abnormalities identified in previous studies. These include various, inconsistent translocations, gains primarily in $3 \mathrm{q}, 4 \mathrm{q}, 5 \mathrm{q}, 9 \mathrm{q}, 11 \mathrm{q}, 12 \mathrm{q}$, and $20 \mathrm{q}$, and losses occurring in $6 \mathrm{q}, 8 \mathrm{p}, 13 \mathrm{q}, 15 \mathrm{q}$, and $17 p$ [19, 23-27]. The many discoveries of chromosomal abnormalities have assisted in the identification of SMZL, but understanding the mechanistic progression of the disease has still eluded investigators in cytogenetic investigations.

Along with the challenge posed by the heterogeneity of chromosomal aberrations, finding patterns among other biological indicators has proven equally as difficult. While cytogenetic investigations have been cited for their importance, it has been suggested that targeting gene mutations will provide more clinical relevance than the former [28]. In an effort to identify crucial genetic abrogates, a number of genetic mutations and deletions have been investigated for their roles in the NF- $\mathrm{KB}$ pathway, cell communication, apoptosis, metabolism, cell cycle control, lymphocyte development, and chromosomal and transcriptional regulation (Table 1).

While each study puts forth potential genetic targets for unraveling the pathogenesis of SMZL, there are still wide discrepancies among which targets will be most fruitful for further investigations. The chromosomal and genetic abnormalities most commonly annotated, along with their frequencies seen across SMZL, are provided in Table 2. Insight into the abnormal genetic landscape and transcriptional regulation of SMZL has presented a plethora of candidates for diagnosing and elucidating SMZL, but similar to the results of cytogenetic studies, conclusions identified from DNA-level mutations do not provide transparent explanations for fully deciphering the biology behind the progression and heterogeneity of SMZL.

To better understand SMZL, studies into various regulatory mechanisms should be conducted as an attempt at explaining the heterogeneity among chromosomal and genetic aberrations. One mechanism of post-transcriptional regulation is via epigenetic modifications, primarily being methylation of DNA promotor sequences. Deregulated DNA methylation has been implicated in the development of similar B-cell malignancies [54-58], and hence, Arribas et al. published a genome-wide DNA-promoter methylation profiling study in an effort to characterize the differential patterns within SMZL [59]. A cohort of patients was identified with significantly increased promotor methylation, and it was associated with a decreased OS compared to patients without the increased methylation profile. Additionally, certain promoter methylation patterns were identified and shown to affect the same biological pathways that were implicated in the genetic studies. While methylation patterns provide one option for mechanistic regulation studies, there are other molecular components worthy of investigation as well in an effort to improve comprehension of SMZL pathology.

\section{MicroRNAs and B-cell lymphomas}

Non-coding RNA molecules are regulatory biological elements that warrant further investigation due to their well-established mechanistic impacts and their relationships with genetic and chromosomal aberrations. MicroRNAs (miRNAs), a type of non-coding RNA, are 20 to 22 nucleotide post-transcriptional regulators that have been heavily researched and reported on for their role in various cancers over the past decade [60-62]. MicroRNAs function by targeting complementary messenger RNAs (mRNAs), allowing them to regulate almost any cellular process that is a result of translation. The idea that miRNAs could play a role in lymphomagenesis originated from evidence that the miR-15/16 cluster was frequently deleted in chronic lymphocytic leukemia (CLL), resulting in the loss of tumor suppression [63]. Following this breakthrough, a plethora of studies were conducted to identify other miRNA in CLL pathogenesis as well as other lymphomas [64-66]. By exposing the oncogenic role of miRNA, they became an option for new treatment targets [67], diagnostic and prognostic markers [68, 69], and mechanism manipulation candidates $[68,70]$.

Preliminary studies have been conducted on the miRNA profile of SMZL, but the role for specific miRNA on SMZL pathogenesis remains to be discovered. Previous investigations into miRNA signatures of similar neoplasms may be informative for deciphering mechanistic impacts of deregulated miRNA in SMZL. Fortunately, unlike SMZL, many B-cell lymphomas have had their miRNA profiles investigated and reviewed extensively. Some miRNAs that are recurrently deregulated among B-cell lymphomas have been elucidated due to their role in B-cell development, migration, or activation [71]. Additional miRNAs also repeatedly identified in B-cell lymphomas are deregulators of "hallmark" cancer functions such as increased proliferation, evasion of suppressors, mortality resistance, and others [72]. The miRNAs consistently identified across B-cell lymphoma studies to be abnormally expressed include: miR-34a, miR-155, the miR-17/92 cluster, miR21 , and miR-150, with many more additional markers also discussed [62, 68, 71-74]. Many of these markers have also been found to be differentially expressed in SMZL miRNA profiles, but due to the exhaustive reporting on these miRNAs in B-cell lymphomas, no further discussion will be provided in this review regarding their potential role in lymphomagenesis. Instead, this review will provide an overview of the unique miRNAs hypothesized to play a role in SMZL pathogenesis. Furthermore, we propose why these miRNA targets warrant future investigations and discuss their oncogenic potential. A summary of all miRNAs reported to be relevant to the biology of SMZL is captured in Table 3. 
Table 1: Summary of significantly deregulated genes and their resultant affected pathways in SMZL

\begin{tabular}{|c|c|c|}
\hline Pathway & Deregulated genes & Citation \\
\hline $\mathrm{NF}-\kappa \mathrm{B}$ & $\begin{array}{l}\text { IKBKB, TNFAIP3 (A20), BIRC3, TRAF3, } \\
\text { MAP3K14, CD40, SYK, BTK, PKCA, REL, } \\
\text { TRAF5, PTPRC, PTPN1, TNFRSF5, LTB, } \\
\text { MYD88, CARD11, FAS, CREBBP, NFKBIZ, KLF2 }\end{array}$ & {$[6,28-38,41]$} \\
\hline Cell Communication & $\begin{array}{l}\text { MS4A2, SYK, TOSO, SELL, LPXN, PTPRC, } \\
P T P N 1, R A S S F 2, B I R C 3, T N F R S F 5, T R A F 3, \\
\text { TRAF5, ENPP2, BTK, PDE4B, PLEXINA2, } \\
\text { ARHGAP25, ARHGAP32, MYCBP2, FLNC, } \\
L C P 1, C A L U\end{array}$ & {$[30,33,36,37,39,43]$} \\
\hline Apoptosis & $\begin{array}{l}\text { BIRC3, TNFRSF5, TRAF3, TRAF5, BTK, APAF-1, } \\
X P B\end{array}$ & {$[30,36,39]$} \\
\hline Metabolism & $\begin{array}{l}\text { UBD, SYK, E2F5, SP140, PFTK1, LPXN, PTPRC, } \\
\text { PTPN1, TNFRSF5, EIF4B, BTAF1, AMPD3, } \\
\text { POU2AF1, EGR2, ENPP2, BTK, ICSBP1 }\end{array}$ & {$[30,33]$} \\
\hline Cell Cycle Control & $\begin{array}{l}\text { CDKN2A, CUL1, TP53, ARID3A, JUN, JUNB, } \\
J U N D, F O S, E V I 5, T M E M 209, \text { ZC } 3 H C 1\end{array}$ & {$[27,28,33,36-39,41,43]$} \\
\hline $\begin{array}{l}\text { Lymphocyte Development and } \\
\text { Regulation }\end{array}$ & $\begin{array}{l}\text { NOTCH2, NOTCH1, SPEN, DTX1, SWAP70, } \\
\text { MAML2, BTK, CXCR4, ARID } 3 A, K L F 2, \\
\text { NOTCH3, NOTCH4, PAX5, MAP } 3 K 8, \text { IRF5 }\end{array}$ & {$[27,28,33,34,36,37,39-43]$} \\
\hline $\begin{array}{l}\text { Chromosomal and Transcriptional } \\
\text { Regulation }\end{array}$ & $\begin{array}{l}\text { MLL2, ARID1A, EP300, CREBBP, SIN3A, } \\
\text { TBL1XR1, GPS2, SMYD1, MLL3, ARID4A, } \\
\text { HIST1H1D, HIST1H1E, HIST1H2BI, HIST1H4H, } \\
\text { SMARCA2, CHD2, BCOR, CBFA2T3, BCL6, } \\
\text { POT1, ILF1 }\end{array}$ & {$[27,28,33,34,36-38,40]$} \\
\hline
\end{tabular}

Table 2: Molecular aberrations most prevalent in SMZL, and the frequency of occurrence in SMZL cases

\begin{tabular}{|c|c|c|}
\hline \multicolumn{3}{|c|}{ GENETIC ABNORMALITIES } \\
\hline Gene & Mutation frequency & Citation \\
\hline NOTCH2 & $\sim 40 \%$ & {$[27,28,33,34,36,37,39,40,44]$} \\
\hline$K L F 2$ & $20 \%-40 \%$ & {$[28,41,42]$} \\
\hline 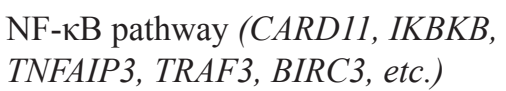 & $35 \%-45 \%$ & {$[28,29,31,33,35-37,41]$} \\
\hline MYD88 & $10 \%-15 \%$ & {$[28,33-35,41]$} \\
\hline TP53 & $10 \%-20 \%$ & {$[28,37,41,45-47]$} \\
\hline \multicolumn{3}{|c|}{ CHROMOSOMAL ABERRATIONS } \\
\hline Location & Incidence & Citation \\
\hline 7q Deletion & $30 \%-40 \%$ & {$[10,16,19-27,43,48-53]$} \\
\hline 3q Gain & $10 \%-20 \%$ & \\
\hline Misc. Gains (6p, 8q, 9q, 12q, 18q) & $8 \%-18 \%$ & \\
\hline Misc. Losses (6q, 8p, 14q, 17p) & $8 \%-16 \%$ & \\
\hline
\end{tabular}


Table 3: Characterization of the miRNA expression (and their location) in SMZL, inclusive of all previously published, relevant studies

\begin{tabular}{|c|c|c|c|}
\hline miRNA & Location & SMZL expression status & Citation \\
\hline miR-155 & $21 \mathrm{q} 21.3$ & $\mathrm{O}$ & {$[77-79]$} \\
\hline $\operatorname{miR}-451$ & $17 \mathrm{q} 11.2$ & $\mathrm{O}, \mathrm{OL}$ & {$[73,77]$} \\
\hline miR-486 & $8 \mathrm{p} 11.21$ & $\mathrm{O}, \mathrm{OL}$ & {$[73,77]$} \\
\hline miR-146a & $5 \mathrm{q} 33.3$ & $\mathrm{O}, \mathrm{OL}$ & {$[79,80]$} \\
\hline $\operatorname{miR}-494$ & $14 \mathrm{q} 32.2$ & $\mathrm{O}$ & [79] \\
\hline miR-34a & $1 \mathrm{p} 36.22$ & $\mathrm{O}$ & {$[78,79]$} \\
\hline $\operatorname{miR}-193 b$ & $16 \mathrm{p} 13.12$ & $\mathrm{O}$ & {$[78]$} \\
\hline miR-100 & $11 \mathrm{q} 24.1$ & $\mathrm{O}$ & [78] \\
\hline miR-330 & $19 \mathrm{q} 13.32$ & $\mathrm{O}$ & [78] \\
\hline miR-21 & $17 \mathrm{q} 23.1$ & $\mathrm{O}, \mathrm{UL}$ & {$[77-79]$} \\
\hline miR-144 & $17 \mathrm{q} 11.2$ & $\mathrm{OL}$ & [73] \\
\hline miR-204 & $9 q 21.12$ & OL & [73] \\
\hline miR-212 & $17 \mathrm{p} 13.3$ & OL & [73] \\
\hline miR-409-3p & $14 q 32.31$ & OL & [73] \\
\hline $\operatorname{miR}-421$ & $\mathrm{Xq} 13.2$ & OL & [73] \\
\hline miR-432 & $14 \mathrm{q} 32.2$ & $\mathrm{OL}$ & [73] \\
\hline miR-487a/487b cluster & $14 \mathrm{q} 32.31$ & OL & [73] \\
\hline miR-520d & $19 \mathrm{q} 13.42$ & OL & [73] \\
\hline $\operatorname{miR}-542-3 p$ & Xq26.3 & OL & [73] \\
\hline miR-574 & $4 \mathrm{p} 14$ & OL & [73] \\
\hline miR-595 & $7 \mathrm{q} 36.3$ & OL & [73] \\
\hline $\operatorname{miR}-650$ & $22 \mathrm{q} 11.22$ & OL & [73] \\
\hline miR-29a/29b-1 cluster & $7 \mathrm{q} 32.3$ & U & {$[75-77]$} \\
\hline miR-127 & $14 \mathrm{q} 32.2$ & $\mathrm{U}, \mathrm{OL}$ & {$[73,77,78]$} \\
\hline miR-139 & $11 \mathrm{q} 13.4$ & $\mathrm{U}, \mathrm{OL}$ & {$[73,77]$} \\
\hline miR-335 & $7 \mathrm{q} 32.2$ & $\mathrm{U}$ & {$[21,76,77]$} \\
\hline miR-411 & $14 \mathrm{q} 32.31$ & U & [77] \\
\hline miR-593 & $7 \mathrm{q} 32.1$ & $\mathrm{U}$ & {$[21,76]$} \\
\hline miR-129-1 & $7 \mathrm{q} 32.1$ & $\mathrm{U}$ & {$[21,76]$} \\
\hline miR-139-5p & $11 \mathrm{q} 13.4$ & $\mathrm{U}$ & [79] \\
\hline miR-345 & $14 q 32.2$ & $\mathrm{U}$ & [79] \\
\hline miR-95 & $4 \mathrm{p} 16.1$ & $\mathrm{U}, \mathrm{OL}$ & {$[73,79]$} \\
\hline miR-138 & $3 \mathrm{p} 21.32$ & $\mathrm{U}$ & [79] \\
\hline $\operatorname{miR}-125 a-5 p$ & $19 \mathrm{q} 13.41$ & U & {$[79]$} \\
\hline $\operatorname{miR}-126$ & $9 q 34.3$ & $\mathrm{U}, \mathrm{OL}$ & {$[73,79]$} \\
\hline
\end{tabular}

(Continued) 


\begin{tabular}{|c|c|c|c|}
\hline miRNA & Location & SMZL expression status & Citation \\
\hline miR-146b-5p & $10 \mathrm{q} 24.32$ & $\mathrm{U}$ & {$[79]$} \\
\hline miR-223 & $\mathrm{Xq} 12$ & $\mathrm{U}$ & [80] \\
\hline $\operatorname{miR}-377$ & $14 q 32.31$ & $\mathrm{U}$ & [78] \\
\hline $\operatorname{miR}-27 b$ & $9 q 22.32$ & $\mathrm{U}$ & [78] \\
\hline miR-145 & $5 q 32$ & $\mathrm{U}$ & [78] \\
\hline miR-376a/376b cluster & $14 \mathrm{q} 32.31$ & $\mathrm{U}$ & [78] \\
\hline miR-381 & $14 q 32.31$ & $\mathrm{U}$ & [78] \\
\hline miR-494 & $14 q 32.31$ & $\mathrm{U}$ & [78] \\
\hline miR-382 & $14 q 32.31$ & $\mathrm{U}$ & [78] \\
\hline $\operatorname{miR}-154$ & $14 q 32.31$ & $\mathrm{U}$ & [78] \\
\hline $\operatorname{miR}-410$ & $14 \mathrm{q} 32.31$ & $\mathrm{U}$ & [78] \\
\hline $\operatorname{miR}-758$ & $14 \mathrm{q} 32.31$ & $\mathrm{U}$ & [78] \\
\hline $\operatorname{miR}-485-3 p$ & $14 \mathrm{q} 32.31$ & $\mathrm{U}$ & [78] \\
\hline miR-136 & $14 q 32.31$ & $\mathrm{U}, \mathrm{OL}$ & {$[73,78]$} \\
\hline miR-379 & $14 \mathrm{q} 32.31$ & $\mathrm{U}$ & [78] \\
\hline miR-338 & $17 \mathrm{q} 25.3$ & $\mathrm{U}$ & [78] \\
\hline miR-107 & $10 \mathrm{q} 23.31$ & $\mathrm{U}$ & {$[78]$} \\
\hline $\operatorname{miR}-24$ & $9 \mathrm{q} 22.32$ & $\mathrm{U}$ & [78] \\
\hline miR-328 & $16 \mathrm{q} 22.1$ & $\mathrm{U}$ & [78] \\
\hline $\operatorname{miR}-199 a$ & $19 \mathrm{p} 13.2$ & $\mathrm{U}$ & [78] \\
\hline $\operatorname{miR}-483$ & $11 \mathrm{p} 15.5$ & $\mathrm{U}$ & {$[78]$} \\
\hline $\operatorname{miR}-589$ & $7 \mathrm{p} 22.1$ & $\mathrm{U}, \mathrm{UL}$ & {$[78]$} \\
\hline miR-182/96/183 cluster & $7 \mathrm{q} 32.2$ & UL & {$[21,76]$} \\
\hline $\operatorname{miR}-26 b$ & $2 q 35$ & UL & {$[78]$} \\
\hline miR-19b & $13 \mathrm{q} 31.3$ & UL & {$[78]$} \\
\hline miR-660 & Xp11.22 & UL & {$[78]$} \\
\hline miR-448 & $\mathrm{Xq} 23$ & UL & [78] \\
\hline miR-646 & $20 \mathrm{q} 12.33$ & UL & [78] \\
\hline miR-323 & $14 q 32.31$ & UL & [78] \\
\hline miR-567 & $3 \mathrm{q} 13.2$ & UL & [78] \\
\hline miR-141 & $12 \mathrm{p} 13.31$ & UL & [73] \\
\hline miR-199b & $9 \mathrm{q} 34.11$ & UL & [73] \\
\hline miR-200c & $12 \mathrm{p} 13.31$ & UL & [73] \\
\hline miR-210 & $11 \mathrm{p} 15.5$ & UL & [73] \\
\hline miR-663 & 20p11.1 & UL & {$[73]$} \\
\hline miR-99a & $21 \mathrm{q} 21.1$ & UL & [73] \\
\hline
\end{tabular}

Abbreviations: O, overexpressed compared to normal spleen; U, under-expressed compared to normal spleen; UL, underexpressed compared to B-cell lymphomas; OL, over-expressed compared to B-cell lymphomas. 


\section{miRNAs in SMZL}

The first study to propose a biological effect by miRNA on SMZL was published by Ruiz-Ballesteros et al. in 2007 and reported decreased expression levels of miR-29a and miR-29b-1 [75]. The two miRNA were chosen for the first study due to their proximity to the commonly deleted $7 \mathrm{q}$ region mentioned above, and miR$29 \mathrm{a}$ is also known to have the potential to target and regulate TCL1A, a predicted oncogene in SMZL [30, 81]. Subsequent studies followed, also investigating the association between miRNA levels and $7 \mathrm{q}$ mutational status. Watkins et al. reported a reduction in the expression of 7 miRNA located at 7q32, consistent with the chromosomal report of $\mathrm{LOH}$ at that location $[21,76]$. This sentinel finding ignited curiosity within the scientific community regarding the role of miRNA and $7 \mathrm{q} \mathrm{LOH}$ and should be further investigated to identify possible mechanistic connections.

The miRNA landscape of SMZL was also studied beyond the miRNA located at 7q32. Bouteloup et al. identified a significant variation in expression of 7 miRNAs when comparing healthy samples to SMZL samples, with two of the identified miRNA being located at $7 \mathrm{q}$ [77]. Additionally, miR-21 over-expression was associated with the aggressiveness of SMZL cases in their study. A report published in 2012 investigated 8 different B-cell lymphomas for specific miRNA signatures within each respective malignancy [73]. SMZL was included in this study, finding 26 different miRNAs to be differentially expressed in SMZL, with 20 being upregulated and 6 being downregulated in SMZL when compared to the other B-cell lymphomas. Arribas et al. conducted a more comprehensive analysis of the miRNA profile for SMZL, finding over 30 miRNAs differentially expressed when compared to reactive spleens, with 9 miRNAs differentially expressed from similar B-cell lymphoma miRNA profiles [78]. Lastly, a study designed to investigate the SMZL miRNA profile, as well as the role of Hepatitis-C Virus on SMZL miRNA, determined a key role for 12 differentially expressed miRNAs in SMZL [79].

Incredibly, across each of the studies, very few miRNAs were found to be differentially expressed in multiple instances (Table 3). The variability among the miRNA profiles once again demonstrates the heterogeneity across SMZL, but due to the preliminary nature of the SMZL miRNA knowledge, as well as the vast regulatory ability of each miRNA, further investigation into their role on SMZL pathogenesis holds many opportunities. The identification of potential candidates for mechanistic studies is the next step to uncovering how posttranscriptional regulation influences SMZL progression. Taken together, the following miRNA are proposed candidates for subsequent studies that should be conducted in an effort to elucidate the biology of SMZL.

\section{Mechanistic impact of miRNA}

The nearly infinite number of mechanistic roles performed by miRNA have been well established in the literature. Sifting through the abundance of the miRNAs for their role in diseases, however, can prove tedious. Hence, we took a reductionist approach by looking at the known role of miRNA in SMZL that are located within the $7 \mathrm{q}$ region and a select few of the miRNA that target caveolin-1 (CAV1). We listed each of the miRNA identified to be differentially expressed in SMZL signatures (Table 3), and we propose 7 of those miRNAs contain potential to be significant contributors to SMZL pathogenesis. These miRNAs are categorized into two different designations in an attempt to delineate the roles that these pathways may play on this specific lymphomagenesis (Table 4).

The miRNAs located at the $7 \mathrm{q}$ region have been hypothesized to play a role in SMZL progression, and due to the frequency of 7q chromosomal abnormalities seen in SMZL, should be investigated for their role. Hence, the first categorical designation will be miRNA that are transcribed within the 7q region. This includes miR-29a/b-1, miR-1291, the miR-183/96/182 polycistron, and miR-335.

The other category corresponds to miRNA that directly target the mRNA of $C A V 1$, a gene located at $7 \mathrm{q} 31$ that has been implicated in similar B-cell lymphomas. There were 9 miRNAs differentially expressed in previous studies that target $C A V 1$, and of the 9, this review will discuss 3 of the miRNAs that could be crucial for exposing a role for $C A V 1$ in SMZL pathogenesis. These miRNAs discussed below include: miR-199a, miR-376, and miR-485. The possibilities for the role of miRNAs in SMZL are almost limitless, but this review provides an evidence-based list of 7 miRNAs that could be crucial to understanding this malignancy.

\section{miRNA located at $7 q$}

The LOH near the $7 \mathrm{q} 32$ chromosomal region is a disruption unique to few lymphomas, and the loss seen in up to $40 \%$ of SMZL patients is the highest among B-cell lymphomas. As previously discussed, this unique aberration is being utilized in diagnostic techniques for SMZL, but the biological mechanisms behind these losses are difficult to identify. While some groups have hypothesized that miRNA could play a role in this $\mathrm{LOH}$, and others have even looked at the miRNA expression profiles within the $7 \mathrm{q} 32$ region in SMZL tissues, the mechanistic role for these miRNA remains to be discovered. The 4 miRNAs below demonstrated significantly lower expression in SMZL cases against healthy samples or similar malignancies. This differential expression was seen across multiple studies in most cases, and the variable expression's consequent downstream regulatory alterations may prove important for SMZL pathogenesis. 
Table 4: Identification of the miRNA at the 7q region, or those that target the oncogene/tumor suppressor caveolin-1

\begin{tabular}{llll}
\hline Category & miRNA & Regulation type & $\begin{array}{c}\text { Proposed SMZL } \\
\text { regulation target }\end{array}$ \\
\hline Transcribed at $7 \mathrm{q}$ & miR-29a/b-1 cluster & Tumor Suppressor & TCL1A \\
& miR-129-1 & Tumor Suppressor & BCL2 \\
& miR-182/96/183 cluster & Tumor Suppressor or Oncogene & FOXO1 \\
& miR-335 & Tumor Suppressor & Rb1, BCL-w \\
Target CAV1 & miR-199a & Tumor Suppressor & IKK, CAV1 \\
& miR-376 & Tumor Suppressor & IGF $1 R, C A V 1 / I G F 1 R / S R C$ \\
\hline
\end{tabular}

The proposed target of regulation within SMZL cells is also described.

\section{miR-29a/b-1 cluster}

The miR-29 family contains a two-member miRNA cluster located distally to a commonly deleted region of 7q, 7q32. The miRNA family contains four members, miR29a, miR-29b-1, miR-29b-2, and miR-29c. While the cluster contains the same seed sequence, resulting in many of the same targets and regulations, only miR-29a and miR-29b-1 are located on 7q. miR-29 is commonly under-expressed in SMZL spleens when compared with healthy tissues. This decrease of expression is consistent with the expression seen in similar B-cell neoplasms, CLL and mantle cell lymphoma (MCL), as well as many other malignancies $[61,67,82-85]$. The variable expression of miR-29 has been viewed with such importance that utilization in diagnostic, and more importantly prognostic, lymphoma designations have been proposed [86]. The regulatory role of miR-29 has been implicated in immune regulation, cell proliferation, differentiation and apoptosis pathways, metastatic interference, and even epigenetic modulation [87]. Due to the myriad of regulatory mechanisms and variable malignancies affected, miR-29 acts as a tumor suppressor in some situations while displaying oncogenic tendencies in others. The replicated under-expression of miR-29 seen in SMZL is consistent with miR-29 levels observed in similar B-cell malignancies, indicating that miR-29 primarily is acting as a tumor suppressor in SMZL. Further, in situations of $\mathrm{LOH}$ at or near the $7 \mathrm{q} 32$ region, there could be complete loss of miR-29 transcripts resulting in possible loss of its tumor suppressive activity and a much more aggressive progression of the malignancy. Further studies are necessary to find the precise mechanistic role of 7q32 status on miR-29 and the overall impacts on SMZL progression.

Due to the established research into the role of miR29 in lymphomas similar to SMZL, the hypothesized mechanistic investigations have promising directionality. A primary target of miR-29a is the mRNA of TCL1A, and upon binding to the TCL1A mRNA it deactivates the oncogenic properties of the impending protein. TCL1A is an oncogene that has been shown to enhance cancer progression via its role in cell survival pathways, and it is commonly over-expressed in aggressive subtypes of many cancers. It has been shown that miR-29a acts as an inhibiting regulator of TCL1A in CLL [88], and as miR29 has a reduction in expression, TCL1A demonstrated the corresponding increase in expression in those cases. TCL1A has been shown to have increased expression among SMZL cases [30], and thus, a similar mechanistic role for miR-29 in SMZL is not out of the question. As mentioned above, in SMZL cases with which the $7 \mathrm{q} 32$ region is deleted, miR-29a could also be deleted. It has also been observed in former studies that miR-29a may be underexpressed in SMZL cases, regardless of $7 \mathrm{q}$ mutational status [75]. This deletion or reduction in expression could result in a lack of TCL1A silencing, and consequently, would promote lymphomagenesis due to the down-stream protein's increased activation and corresponding effects. Due to the multifaceted regulatory mechanisms of miR29 , multiple cellular processes are disrupted upon its down regulation, as is seen in SMZL, but specific investigations into the tumor suppressive mechanisms, like the impact on TCL1A, are necessary for the exploitation of miR-29 in treatment and diagnostic opportunities.

\section{miR-129-1}

The miR-129 family is composed of miR-129-1 and miR-129-2, with the former being located at 7q32 within the region most commonly deleted in SMZL presentations. The two miRNA have almost identical seed sequences, resulting in similar functionalities. miR-129 has been primarily identified for its tumor suppressive role in various tumorigeneses, but oncogenic properties of the miRNA have been discovered as well. miR-129-1 was shown to have repressed expression of in SMZL. Thus, tumor suppression 
is most likely the route of regulation for this specific malady. Other cancers have also been found to display under-expression of miR-129, with a plethora of proposed mechanistic explanations from cell proliferation, cell cycle, apoptotic, metastatic, and autophagy pathway regulations [89]. Karaayvaz et al. investigated the regulation by miR129 as a tumor suppressor, finding that through direct targeting of B-cell lymphoma 2 (BCL2), miR-129 induces apoptotic mechanisms and inhibits cell proliferation via cellcycle arrest in colorectal cancer cells [90]. Consequently, upon decreased expression of miR-129, each of the tumor suppressive mechanisms are also stifled. A similar situation may occur in SMZL, as miR-129 shows decreased expression compared with healthy samples. Further, BCL2 has been found to be over-expressed in SMZL signatures [78], providing additional evidence for the practicality of the miR-129 regulatory impact. Investigations into the role of miR-129-1 on SMZL pathogenesis and 7q LOH may prove beneficial based on reported information mentioned above, and thus, the mechanistic understanding of miR-129 related to SMZL should be improved.

\section{miR-182/96/183 cluster}

The miRNA polycistron consisting of miR-182, miR-96, and miR-183 is considered a cluster due to the miRNAs' proximity to one another. The miR-183 cluster is located at $7 \mathrm{q} 32$, and the miRNAs possess similar seed sequences, resulting in many shared functionalities. These miRNAs are typically seen over-expressed in various cancers, but under-expression has also been observed, demonstrating the dual tumor-suppressive and oncogenic role of the polycistron. More specifically, an increased expression of miR-183 was reported in lung cancer tissues [91], but in a separate study, miR-183 was found to have decreased expression in the peripheral blood of lung cancer cases [92], indicating miR-183 is utilized for contradictory mechanistic interactions in hematological and tissue malignancies. As for previously published miRNA data in SMZL, the miR-183 cluster has been shown to be under-expressed when compared to similar B-cell lymphoma samples [76]. The expression values when compared to control samples were unavailable, though. Thus, the under-expression seen in SMZL could be the result of an increase in tumor suppressive properties, or it could be an indication for a reduction in oncogenic effects compared to the B-cell lymphoma counterparts. A polymorphic mutation in approximately one quarter of SMZL cases has also been found at the region containing miR-182, indicating possible loss of function in some SMZL cases [76], but it has also been shown that the polymorphism can be found among healthy populations at an only slightly lower occurrence bringing into question its carcinogenicity [93]. This alteration in miR-182 expression should first be investigated for the in-question dependence to the aforementioned polymorphism, but regardless, the under-expression of the entire miR-183 cluster seen in SMZL indicate it should be assessed for its possible mechanistic role in the $7 \mathrm{q}$ deletion.

A variety of malignancies have been investigated for connections to the aberrant role of miR-183 cluster members on carcinogenesis, but conflicting mechanistic actions in varying tissues and malignancies make this evaluation inconsistent. The cluster is commonly overexpressed in many solid tumors, but there has also been significant under-expression of the cluster in other malignancies [94]. Even among hematological malignancies expression is variable. MCL cases present with an increased miR-182 expression [95], but CLL cases showed a p53 regulated decrease in miR-182 expression $[73,96]$. Mechanistic relationships between miR-183 cluster members have stretched to many pathways and functions. There has been regulation in cell proliferation, cell apoptosis, cell migration, immune signaling, and DNA repair mechanisms, indicating the wide carcinogenic outreach of the cluster [97]. Connections to sonic hedgehog signaling pathways, Pro-apoptotic Programmed Cell Death (PDCD) family regulation, and regulation of Forkhead Box O (FOXO) subfamily signaling, just to name a few, have been published for explanations of the role the miR-183 cluster, or one of its' members, has on various tumorigenesis processes [95, 98-109]. With such an impactful list of vetted carcinogenic targets, studies establishing the miR-183 cluster expression profile in SMZL against healthy/control tissues, and further investigation into the role of the cluster on SMZL pathogenesis, could renders vital for understanding the possible function of 7q LOH in SMZL overall progression.

\section{miR-335}

The final miRNA of interest located within the $7 q$ region is miR-335. Similar to the other miRNA of interest, miR-335 was significantly under expressed in SMZL samples when compared to healthy controls. Research on miR-335 has been done primarily on solid tumor malignancies but the mechanistic conclusions in studies have the potential to be translated further [110]. miR335 has been discussed for its role as an oncogene, but it has contrarily been found to act as a tumor suppressor in other malignancies. Many of the cancers displaying an under-expression of miR-335, like SMZL, point to tumor suppressive mechanisms as its role in carcinogenesis.

One mechanism of action with far-reaching impacts demonstrated the role of miR-335 in p53 regulation. Scarola et al. found that miR-335 targets and represses retinoblastoma $1(R B 1)$ resulting in the up-regulation of p53 [111], but p53 pathway activation results in further up-regulation of miR-335, hence triggering a positive feedback loop. Thus, in a malignancy like SMZL when miR-335 is under-expressed, or in a case of $7 q$ deletion possibly eliminating the coding regions for miR- 
335 rendering it almost nonexistent, there is no down regulation of $R B 1$ and no downstream activation of $\mathrm{p} 53$, resulting in a huge decrease in the wide-spread tumor suppression. Additionally, TP53 deletions and mutations have been shown in $15 \%-25 \%$ of SMZL cases [27, $28,38,47]$, which would also result in disruption of the aforementioned positive feedback loop. Hence, this would provide an additional explanation for the decrease in miR335 expression. Further investigations into this mechanistic relationship may prove crucial for understanding miR-335 as well as TP53 functioning in SMZL.

In other work, miR-335 has been shown to regulate BCL-w, a member of the BCL-2 protein family, suppressing its role in cell proliferation pathways, resulting in apoptosis of tumor cells [112, 113]. Again, as miR-335 is acting as a tumor suppressor, its underexpression would result in less suppression of $B C L-W$ allowing the tumor cells to proliferate much easier promoting their survival. Either of the aforementioned mechanisms could prove helpful in understanding SMZL, as p53 is a universal tumor suppressor that impacts all malignancies, and the B-cell lymphoma protein family is extremely homogeneous and miR-335 targeting of other $B C L$ homologues should not be overlooked.

\section{miRNA targeting $C A V 1$ in SMZL}

The LOH at $7 q$ in SMZL has not been fully elucidated due to the many regulatory mechanisms that are possibly responsible or work in conjunction to impose the aberration. The fragile site FRA7G overlaps with part of the $7 \mathrm{q}$ region commonly deleted in SMZL, and within that site, at $7 \mathrm{q} 31.2$ to be exact, the tumor suppressor and oncogene, $C A V 1$, resides. Therein other instances of $\mathrm{LOH}$ involving $C A V 1$ resulted in malignant transformations $[114,115]$. When $C A V 1$ is coupled with an oncogene, $C A V 1$ knockout mice appear more prone to progress to aggressive forms of cancers than in mice without the CAV1 knockout [116]. This impact could prove crucial for deciphering SMZL within an in vivo model and hence has been recently proposed [117]. The fragility and importance of the $7 q$ region in SMZL almost certainly implicates $C A V 1$ as a significant player in the disease etiology due to its crucial chromosomal location. Thus, the mechanisms and regulatory pathways extrapolating the role of $C A V 1$ in SMZL pathogenesis are worthy of further investigation.

There have been discrepancies among reported results regarding $C A V 1$ status in SMZL cases. RuizBallesteros et al. showed decreased expression of CAVI [30], but Watkins et al. found no differential regulation of CAV1 in SMZL samples [21]. These inconsistencies may be a result of additional molecular regulators and their impacts. There are 9 miRNAs reported to be aberrantly expressed in the SMZL profile, that have the ability to target $C A V 1$, and thus, it would be no surprise if miRNAs regulation on $C A V 1$ may be the culprit responsible for these discrepancies. Further, $C A V 1$ expression has been reported to be independent of $7 \mathrm{q}$ mutation status also supporting the idea that regulatory mechanisms beyond chromosomal loss are almost certainly at work. $C A V 1$ has been shown to be a crucial piece in immune functioning and dysregulation in malignancies similar to SMZL, and in order to decipher the role of $C A V 1$ on SMZL, in cases of $7 \mathrm{q} \mathrm{LOH}$ or in cases with $7 \mathrm{q}$ intact, miRNA regulation should be investigated for their impact. There are 3 miRNAs (miR-199a, miR376 cluster, and miR-485) that will be discussed next that present viable options for CAV1 regulation and, in turn, impact SMZL pathogenesis (Figure 1).

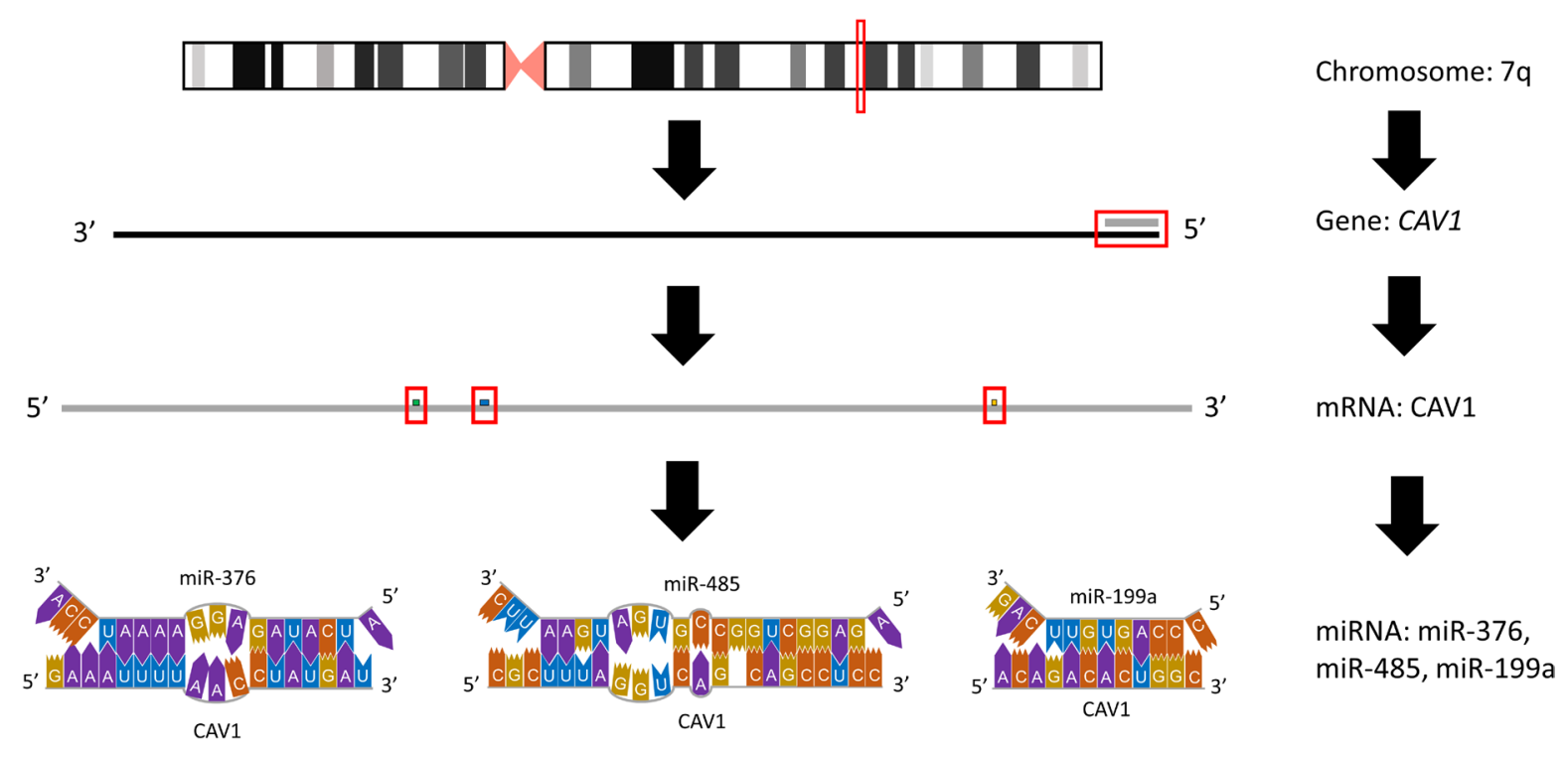

Figure 1: Graphical representation of affected region on 7q. The predominantly affected region of chromosome 7 frequently mutated or lost in splenic marginal zone lymphoma is depicted, inclusive of the miRNA within this region that target $C A V 1$. 


\section{miR-199a}

The decreased expression of miR-199a seen in SMZL is consistent with previously published literature. In studies to this point, miR-199a has demonstrated tumor suppressive properties, and hence, has been under-expressed in many of the malignancies being investigated. Due to its importance as a tumor suppressor it has been studied for its prognostic significance and potential as a treatment target in solid and hematological malignancies [118]. Many studies have demonstrated the multifaceted, tumor suppressive properties of miR199a. The decreased expression of miR-199a induces an increase in IKK $\beta$ activity, further stimulating the NF- $\mathrm{KB}$ pathway, which results in an enhanced tumor environment and chemoresistance [119-121]. The proposed tumor suppressive mechanisms of miR-199a have also included downregulation of proto-oncogenes and their corresponding pathways [122], as well as regulation of mammalian target of rapamycin, cell migration, and apoptotic pathways [118]. In the malignancy most similar to SMZL, diffuse large B-cell lymphoma (DLBCL), the increased expression of miR-199a among patient cohorts has corresponded to a more favorable progression free survival and OS [118, 123].

While pathway regulation is important for elucidating the role of miR-199a, in order to exploit miR199a for more treatment and prognostic options precise mechanistic understanding must be improved. There has been research into the mechanistic relationship that miR-199a and the tumor suppressor and oncogene CAVI may have. miR199a has been shown to directly target $C A V 1$ and, in turn, affect the resulting mechanisms in which CAV1 may be involved [124]. Subsequent studies further supported this relationship and have found miR199a significantly inhibits CAV1 expression and function [125]. Thus, when miR-199a is shown to have decreased expression in SMZL cases, an increased expression of $C A V 1$ could be expected, which has shown to be detrimental in other cancers [126-130]. Experimental investigations into the relationship between $C A V 1$ and miR-199a may not only prove beneficial for understanding its role in SMZL progression but could render fruitful for deciphering other malignancies and diseases as well.

\section{miR-376 cluster}

An additional target of $C A V 1$, the miR-376 cluster, was also significantly under-expressed in SMZL compared to non-tumoral controls [78]. The miR-376 family has not been studied extensively, but it has been shown to act with oncogenic properties in some malignancies while displaying tumor suppressive functions in other cancers, resulting in proposed utilization as a biomarker [131133]. The decrease in miR-376 expression in SMZL cases indicates tumor suppressive properties, but the mechanistic understanding of miR-376 remains unknown. miR-376 has been shown to impact cancer progression via cell cycle progression, cell migration and invasion, and autophagy [134-136]. One mechanism of tumor suppression is the direct regulation of $I G F 1 R$ by miR-376a and miR-376c, resulting in decreased migration and proliferation [134]. Thus, upon reduction of miR-376a expression, as is seen in SMZL, IGFIR becomes fully activated, promoting tumor progression. Additionally, IGF1R forms a complex with CAV1 and SRC in order to induce anti-apoptotic mechanisms [137]. When inhibition of CAV1 or IGF1R was applied, it corrupted the complex allowing apoptotic molecules to resume mitigating tumor development. This identifies another route that miR-376 may serve as a tumor suppressor, as it would be able to directly target and suppress $C A V 1, I G F 1 R$, or both, to disrupt their oncogenic mission. Hence, the decrease in miR-376 in SMZL would limit the capacity for these tumor suppressive functions.

Arribas et al. hypothesized additional predicted targets of miR-376 that have been shown to act in tumorigenesis: CD44, MUM1, DLEU1, IL2RA, IL7, IRTA4, and FOXP1 [78], all of which could potentially be upregulated in SMZL. Upregulation of FOXP1, for example, has been demonstrated in SMZL [78]. It is similarly upregulated in DLBCL signatures, resulting in increased oncogenic activity [138]. This upregulation of FOXP1 and subsequent increase in malignant activity would be consistent with a decrease in miR-376 expression, and thus, this relationship should be further explored. Finally, miR-376 has been shown to undergo RNA editing, resulting in altered mRNA targets, in germinal center based B-cell lymphomas [139]. This alteration in targets can result in a multitude of aberrant regulations, possibly even becoming carcinogenic. And, while the cellular origin of SMZL is still controversial, it's plausible that RNA editing within the miR-376 could assist in tracking etiology in a subset of cases. Each of the aforementioned mechanisms present the capability to contribute to SMZL pathogenesis understanding the impact of miR-376 on SMZL and other malignancies should be pursued.

\section{miR-485}

The final miRNA of interest in this review is miR-485. Arribas et al. demonstrated significant under expression of miR-485 in SMZL samples [78]. The decreased expression is consistent with many of the previously published findings on miR-485, and it indicates the miRNA exhibits primarily tumor suppressive properties on SMZL pathogenesis. Increased expression of miR-485 has corresponded to enhanced treatment resistances in tumor cells [140, 141], and increased expression has also been shown to impact cell migration and invasion, colony formation, cell viability, and mitochondrial functioning in tumor cells, resulting in decreased cell viability [142, 143]. Additionally, decreased expression of miR-485 
has corresponded to less desirable outcomes in clinical studies indicating possible functionality as a biomarker $[144,145]$. One proposed mechanism of the tumor suppressive role of miR-485 is the result of a singlenucleotide polymorphism (SNP) at the miR-485 binding site [146]. This SNP abrogates the ability of the miRNA to accurately bind to target mRNAs resulting in loss of tumor suppressive function. Chen et al. also proposed that miR-485 targets pathways involved in topoisomerase inhibition, and through decreased expression of miR485 , there is decreased sensitivity in related treatments [140]. The role of miR-485 on SMZL pathogenesis has yet to be investigated, but its interaction with $C A V 1$, a predicted target of miR-485, is worthy of a further look. The previously proposed mechanisms from altered miRNA regulation due to SNPs or direct regulation of CAVI resulting in downstream effects are both viable possibilities and could be investigated in SMZL cellular environments.

\section{CONCLUSIONS}

Splenic marginal zone lymphoma is an indolent, non-Hodgkin lymphoma with an OS of over 10 years in most cases. Approximately a third of these cases become aggressive and possibly transform to a much more lethal lymphoma, cutting the OS almost in half for those patients. Mechanistic understanding behind this unfavorable prognosis remain unknown, despite a plethora of chromosomal and genetic investigations. The lack of cohesive results in much of the literature may be the result of additional regulatory mechanisms, resulting in abnormal functioning and interactions at the chromosomal and genetic levels. The role of miRNA in cancer is a growing investigative interest, as elucidation of their regulation has proven enlightening for deciphering various malignancies and their progression. This review discusses the discrepancies among current data regarding understanding of SMZL pathogenesis and proposes miRNA regulation to be a possible culprit. The regulation by 7 miRNAs previously identified to have altered expression in SMZL are discussed, and possible mechanisms for their impact on SMZL progression are proposed based on previous findings in other malignancies. The miRNA located within the most commonly effected chromosomal region in SMZL, 7q and the miRNA that target CAV1, a gene implicated in many cancers and located at $7 q 31$, were also a focus of this review. Further investigations into the mechanistic role of miRNA in SMZL may provide insight into the disease etiology and could identify possible candidates for prognostic biomarkers and treatment targets, improving acumen for this disease entity.

\section{CONFLICTS OF INTEREST}

The authors declare no conflicts of interest.

\section{REFERENCES}

1. Arcaini L, Rossi D, Paulli M. Splenic marginal zone lymphoma: from genetics to management. Blood. 2016; 127:2072-81. https://doi.org/10.1182/blood-2015-11-624312.

2. Baliakas P, Strefford JC, Bikos V, Parry M, Stamatopoulos $\mathrm{K}$, Oscier D. Splenic marginal-zone lymphoma: ontogeny and genetics. Leuk Lymphoma. 2015; 56:301-10. https:// doi.org/10.3109/10428194.2014.919636.

3. Zucca E, Bertoni F, Roggero E, Cavalli F. Management of rare forms of lymphoma. Curr Opin Oncol. 1998; 10:37784. https://doi.org/10.1097/00001622-199809000-00002.

4. Liu L, Wang H, Chen Y, Rustveld L, Liu G, Du XL. Splenic marginal zone lymphoma: a population-based study on the 2001-2008 incidence and survival in the United States. Leuk Lymphoma. 2013; 54:1380-86. https://doi.org/10.31 09/10428194.2012.743655.

5. Santos TS, Tavares RS, Farias DL. Splenic marginal zone lymphoma: a literature review of diagnostic and therapeutic challenges. Rev Bras Hematol Hemoter. 2017; 39:146-54. https://doi.org/10.1016/j.bjhh.2016.09.014.

6. Arcaini L, Lazzarino M, Colombo N, Burcheri S, Boveri E, Paulli M, Morra E, Gambacorta M, Cortelazzo S, Tucci A, Ungari M, Ambrosetti A, Menestrina F, et al, and Integruppo Italiano Linfomi. Splenic marginal zone lymphoma: a prognostic model for clinical use. Blood. 2006; 107:464349. https://doi.org/10.1182/blood-2005-11-4659.

7. Chacón JI, Mollejo M, Muñoz E, Algara P, Mateo M, Lopez L, Andrade J, Carbonero IG, Martínez B, Piris MA, Cruz MA. Splenic marginal zone lymphoma: clinical characteristics and prognostic factors in a series of 60 patients. Blood. 2002; 100:1648-54.

8. Olszewski AJ, Castillo JJ. Survival of patients with marginal zone lymphoma: analysis of the Surveillance, Epidemiology, and End Results database. Cancer. 2013; 119:629-38. https://doi.org/10.1002/cncr.27773.

9. Kalpadakis C, Pangalis GA, Angelopoulou MK, Sachanas S, Kontopidou F, Moschogiannis M, Ximeri M, Tsirkinidis P, Yiakoumis X, Papadaki HA, Vassilakopoulos TP. Validation of the simplified prognostic score for splenic marginal zone lymphoma of the Splenic Marginal Zone Lymphoma Working Group. Leuk Lymphoma. 2014; 55:2640-42. https://doi.org/10.3109/10428194.2014.897703.

10. Camacho FI, Mollejo M, Mateo MS, Algara P, Navas C, Hernández JM, Santoja C, Solé F, Sánchez-Beato M, Piris MA. Progression to large B-cell lymphoma in splenic marginal zone lymphoma: a description of a series of 12 cases. Am J Surg Pathol. 2001; 25:1268-76. https://doi. org/10.1097/00000478-200110000-00007.

11. Conconi A, Franceschetti S, Aprile von Hohenstaufen K, Margiotta-Casaluci G, Stathis A, Moccia AA, Bertoni F, Ramponi A, Mazzucchelli L, Cavalli F, Gaidano G, Zucca E. Histologic transformation in marginal zone lymphomas. Ann Oncol. 2015; 26:2329-35. https://doi.org/10.1093/ annonc/mdv368. 
12. Franco V, Florena AM, Iannitto E. Splenic marginal zone lymphoma. Blood. 2003; 101:2464-72. https://doi. org/10.1182/blood-2002-07-2216.

13. Lenglet J, Traullé C, Mounier N, Benet C, Munoz-Bongrand $\mathrm{N}$, Amorin S, Noguera ME, Traverse-Glehen A, Ffrench M, Baseggio L, Felman P, Callet-Bauchu E, Brice P, et al. Long-term follow-up analysis of 100 patients with splenic marginal zone lymphoma treated with splenectomy as firstline treatment. Leuk Lymphoma. 2014; 55:1854-60. https:// doi.org/10.3109/10428194.2013.861067.

14. Matutes E. Clinical and biological diversity of splenic marginal zone lymphoma. Expert Rev Anticancer Ther. 2009; 9:1185-89. https://doi.org/10.1586/era.09.91.

15. Ferreira BI, García JF, Suela J, Mollejo M, Camacho FI, Carro A, Montes S, Piris MA, Cigudosa JC. Comparative genome profiling across subtypes of low-grade B-cell lymphoma identifies type-specific and common aberrations that target genes with a role in B-cell neoplasia. Haematologica. 2008; 93:670-79. https://doi.org/10.3324/ haematol.12221.

16. Boonstra R, Bosga-Bouwer A, van Imhoff GW, Krause V, Palmer M, Coupland RW, Dabbagh L, van den Berg E, van den Berg A, Poppema S. Splenic marginal zone lymphomas presenting with splenomegaly and typical immunophenotype are characterized by allelic loss in 7q31-32. Mod Pathol. 2003; 16:1210-17. https://doi. org/10.1097/01.MP.0000095895.19756.77.

17. Gruszka-Westwood AM, Hamoudi R, Osborne L, Matutes E, Catovsky D. Deletion mapping on the long arm of chromosome 7 in splenic lymphoma with villous lymphocytes. Genes Chromosomes Cancer. 2003; 36:5769. https://doi.org/10.1002/gcc.10142.

18. Viaggi S, Abbondandolo A, Carbone M, Ottaggio L, Sessarego M, Zupo S, Zunino A. Uncommon cytogenetic findings in a case of splenic marginal zone lymphoma with aggressive clinical course. Cancer Genet Cytogenet. 2004; 148:133-36. https://doi.org/10.1016/ S0165-4608(03)00242-5.

19. Hernández JM, García JL, Gutiérrez NC, Mollejo M, Martínez-Climent JA, Flores T, González MB, Piris MA, San Miguel JF. Novel genomic imbalances in B-cell splenic marginal zone lymphomas revealed by comparative genomic hybridization and cytogenetics. Am J Pathol. 2001; 158:1843-50. https://doi.org/10.1016/ S0002-9440(10)64140-5.

20. Mateo M, Mollejo M, Villuendas R, Algara P, SanchezBeato M, Martínez P, Piris MA. 7q31-32 allelic loss is a frequent finding in splenic marginal zone lymphoma. Am J Pathol. 1999; 154:1583-89. https://doi.org/10.1016/ S0002-9440(10)65411-9.

21. Watkins AJ, Huang Y, Ye H, Chanudet E, Johnson N, Hamoudi R, Liu H, Dong G, Attygalle A, McPhail ED, Law $\mathrm{ME}$, Isaacson PG, de Leval L, et al. Splenic marginal zone lymphoma: characterization of 7q deletion and its value in diagnosis. J Pathol. 2010; 220:461-74.

22. Robledo C, García JL, Benito R, Flores T, Mollejo M, Martínez-Climent JA, García E, Gutiérrez NC, Piris MA, Hernández JM. Molecular characterization of the region 7q22.1 in splenic marginal zone lymphomas. PLoS One. 2011; 6:e24939. https://doi.org/10.1371/journal. pone. 0024939 .

23. Andersen CL, Gruszka-Westwood A, Atkinson S, Matutes E, Catovsky D, Pedersen RK, Pedersen BB, Pulczynski S, Hokland P, Jacobsen E, Koch J. Recurrent genomic imbalances in B-cell splenic marginal-zone lymphoma revealed by comparative genomic hybridization. Cancer Genet Cytogenet. 2005; 156:122-28. https://doi. org/10.1016/j.cancergencyto.2004.04.026.

24. Baró C, Salido M, Espinet B, Astier L, Domingo A, Granada I, Millà F, Carrió A, Costa D, Luño E, Hernández JM, Campo E, Florensa L, et al. New chromosomal alterations in a series of 23 splenic marginal zone lymphoma patients revealed by Spectral Karyotyping (SKY). Leuk Res. 2008; 32:727-36. https://doi.org/10.1016/j.leukres.2007.09.012.

25. Martinez-Climent JA, Sanchez-Izquierdo D, Sarsotti E, Blesa D, Benet I, Climent J, Vizcarra E, Marugan I, Terol MJ, Sole F, Cigudosad JC, Siebert R, Dyer MJ, GarcíaConde J. Genomic abnormalities acquired in the blastic transformation of splenic marginal zone B-cell lymphoma. Leuk Lymphoma. 2003; 44:459-64. https://doi.org/10.108 0/1042819021000055129.

26. Traverse-Glehen A, Bachy E, Baseggio L, Callet-Bauchu E, Gazzo S, Verney A, Hayette S, Jallades L, Ffrench M, Salles G, Coiffier B, Felman P, Berger F. Immunoarchitectural patterns in splenic marginal zone lymphoma: correlations with chromosomal aberrations, IGHV mutations, and survival. A study of 76 cases. Histopathology. 2013; 62:876-93. https://doi.org/10.1111/his.12092.

27. Salido M, Baró C, Oscier D, Stamatopoulos K, Dierlamm J, Matutes E, Traverse-Glehen A, Berger F, Felman P, Thieblemont C, Gesk S, Athanasiadou A, Davis Z, et al. Cytogenetic aberrations and their prognostic value in a series of 330 splenic marginal zone B-cell lymphomas: a multicenter study of the Splenic B-Cell Lymphoma Group. Blood. 2010; 116:1479-88. https://doi.org/10.1182/ blood-2010-02-267476.

28. Parry M, Rose-Zerilli MJ, Ljungström V, Gibson J, Wang J, Walewska R, Parker H, Parker A, Davis Z, Gardiner A, McIver-Brown N, Kalpadakis C, Xochelli A, et al. Genetics and prognostication in splenic marginal zone lymphoma: revelations from deep sequencing. Clin Cancer Res. 2015; 21:4174-83. https://doi.org/10.1158/1078-0432. CCR-14-2759.

29. Rossi D, Deaglio S, Dominguez-Sola D, Rasi S, Vaisitti T, Agostinelli C, Spina V, Bruscaggin A, Monti S, Cerri M, Cresta S, Fangazio M, Arcaini L, et al. Alteration of

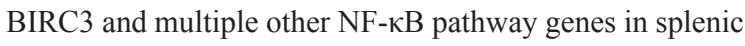


marginal zone lymphoma. Blood. 2011; 118:4930-34. https://doi.org/10.1182/blood-2011-06-359166.

30. Ruiz-Ballesteros E, Mollejo M, Rodriguez A, Camacho FI, Algara P, Martinez N, Pollán M, Sanchez-Aguilera A, Menarguez J, Campo E, Martinez P, Mateo M, Piris MA. Splenic marginal zone lymphoma: proposal of new diagnostic and prognostic markers identified after tissue and cDNA microarray analysis. Blood. 2005; 106:1831-38. https://doi.org/10.1182/blood-2004-10-3898.

31. Spina V, Rossi D. NF- $\kappa$ B deregulation in splenic marginal zone lymphoma. Semin Cancer Biol. 2016; 39:61-67. https://doi.org/10.1016/j.semcancer.2016.08.002.

32. Novak U, Rinaldi A, Kwee I, Nandula SV, Rancoita PM, Compagno M, Cerri M, Rossi D, Murty VV, Zucca E, Gaidano G, Dalla-Favera R, Pasqualucci L, et al. The $\mathrm{NF}-\{\kappa\} \mathrm{B}$ negative regulator TNFAIP3 (A20) is inactivated by somatic mutations and genomic deletions in marginal zone lymphomas. Blood. 2009; 113:4918-21. https://doi. org/10.1182/blood-2008-08-174110.

33. Rossi D, Trifonov V, Fangazio M, Bruscaggin A, Rasi S, Spina V, Monti S, Vaisitti T, Arruga F, Famà R, Ciardullo C, Greco M, Cresta S, et al. The coding genome of splenic marginal zone lymphoma: activation of $\mathrm{NOTCH} 2$ and other pathways regulating marginal zone development. J Exp Med. 2012; 209:1537-51. https://doi.org/10.1084/ jem.20120904.

34. Peveling-Oberhag J, Wolters F, Döring C, Walter D, Sellmann L, Scholtysik R, Lucioni M, Schubach M, Paulli M, Biskup S, Zeuzem S, Küppers R, Hansmann ML. Whole exome sequencing of microdissected splenic marginal zone lymphoma: a study to discover novel tumorspecific mutations. BMC Cancer. 2015; 15:773. https://doi. org/10.1186/s12885-015-1766-Z.

35. Yan Q, Huang Y, Watkins AJ, Kocialkowski S, Zeng N, Hamoudi RA, Isaacson PG, de Leval L, Wotherspoon A, Du MQ. BCR and TLR signaling pathways are recurrently targeted by genetic changes in splenic marginal zone lymphomas. Haematologica. 2012; 97:595-98. https://doi. org/10.3324/haematol.2011.054080.

36. Martínez N, Almaraz C, Vaqué JP, Varela I, Derdak S, Beltran S, Mollejo M, Campos-Martin Y, Agueda L, Rinaldi A, Kwee I, Gut M, Blanc J, et al. Whole-exome sequencing in splenic marginal zone lymphoma reveals mutations in genes involved in marginal zone differentiation. Leukemia. 2014; 28:1334-40. https://doi.org/10.1038/leu.2013.365.

37. Parry M, Rose-Zerilli MJ, Gibson J, Ennis S, Walewska R, Forster J, Parker H, Davis Z, Gardiner A, Collins A, Oscier DG, Strefford JC. Whole exome sequencing identifies novel recurrently mutated genes in patients with splenic marginal zone lymphoma. PLoS One. 2013; 8:e83244. https://doi. org/10.1371/journal.pone.0083244.

38. Rinaldi A, Forconi F, Arcaini L, Mian M, Sozzi E, Zibellini S, Baldini L, Franceschetti S, Gaidano G, Marasca R, Mollejo M, Piris MA, Tucci A, et al. Immunogenetics features and genomic lesions in splenic marginal zone lymphoma. Br J Haematol. 2010; 151:435-39. https://doi. org/10.1111/j.1365-2141.2010.08347.x.

39. Trøen G, Nygaard V, Jenssen TK, Ikonomou IM, Tierens A, Matutes E, Gruszka-Westwood A, Catovsky D, Myklebost O, Lauritzsen G, Hovig E, Delabie J. Constitutive expression of the AP-1 transcription factors c-jun, junD, junB, and c-fos and the marginal zone B-cell transcription factor Notch2 in splenic marginal zone lymphoma. J Mol Diagn. 2004; 6:297-307. https://doi.org/10.1016/ S1525-1578(10)60525-9.

40. Kiel MJ, Velusamy T, Betz BL, Zhao L, Weigelin HG, Chiang MY, Huebner-Chan DR, Bailey NG, Yang DT, Bhagat G, Miranda RN, Bahler DW, Medeiros LJ, et al. Whole-genome sequencing identifies recurrent somatic NOTCH2 mutations in splenic marginal zone lymphoma. J Exp Med. 2012; 209:1553-65. https://doi.org/10.1084/ jem.20120910.

41. Clipson A, Wang M, de Leval L, Ashton-Key M, Wotherspoon A, Vassiliou G, Bolli N, Grove C, Moody S, Escudero-Ibarz L, Gundem G, Brugger K, Xue X, et al. KLF2 mutation is the most frequent somatic change in splenic marginal zone lymphoma and identifies a subset with distinct genotype. Leukemia. 2015; 29:1177-85. https://doi.org/10.1038/leu.2014.330.

42. Piva R, Deaglio S, Famà R, Buonincontri R, Scarfò I, Bruscaggin A, Mereu E, Serra S, Spina V, Brusa D, Garaffo G, Monti S, Dal Bo M, et al. The Krüppel-like factor 2 transcription factor gene is recurrently mutated in splenic marginal zone lymphoma. Leukemia. 2015; 29:503-07. https://doi.org/10.1038/leu.2014.294.

43. Fresquet V, Robles EF, Parker A, Martinez-Useros J, Mena M, Malumbres R, Agirre X, Catarino S, Arteta D, Osaba L, Mollejo M, Hernandez-Rivas JM, Calasanz $\mathrm{MJ}$, et al. High-throughput sequencing analysis of the chromosome 7q32 deletion reveals IRF5 as a potential tumour suppressor in splenic marginal-zone lymphoma. Br J Haematol. 2012; 158:712-26. https://doi. org/10.1111/j.1365-2141.2012.09226.x.

44. Trøen G, Wlodarska I, Warsame A, Hernández Llodrà S, De Wolf-Peeters C, Delabie J. NOTCH2 mutations in marginal zone lymphoma. Haematologica. 2008; 93:1107-09. https:// doi.org/10.3324/haematol.11635.

45. Baldini L, Fracchiolla NS, Cro LM, Trecca D, Romitti L, Polli E, Maiolo AT, Neri A. Frequent p53 gene involvement in splenic B-cell leukemia/lymphomas of possible marginal zone origin. Blood. 1994; 84:270-78.

46. Sol Mateo M, Mollejo M, Villuendas R, Algara P, SánchezBeato M, Martinez-Delgado B, Martínez P, Piris MA. Analysis of the frequency of microsatellite instability and p53 gene mutation in splenic marginal zone and MALT lymphomas. Mol Pathol. 1998; 51:262-67. https://doi. org/10.1136/mp.51.5.262.

47. Gruszka-Westwood AM, Hamoudi RA, Matutes E, Tuset E, Catovsky D. p53 abnormalities in splenic lymphoma with 
villous lymphocytes. Blood. 2001; 97:3552-58. https://doi. org/10.1182/blood.V97.11.3552.

48. Dierlamm J, Rosenberg C, Stul M, Pittaluga S, Wlodarska I, Michaux L, Dehaen M, Verhoef G, Thomas J, de Kelver W, Bakker-Schut T, Cassiman JJ, Raap AK, et al. Characteristic pattern of chromosomal gains and losses in marginal zone B cell lymphoma detected by comparative genomic hybridization. Leukemia. 1997; 11:747-58. https://doi. org/10.1038/sj.leu.2400635.

49. Solé F, Salido M, Espinet B, Garcia JL, Martinez Climent JA, Granada I, Hernández JM, Benet I, Piris MA, Mollejo M, Martinez P, Vallespí T, Domingo A, et al. Splenic marginal zone B-cell lymphomas: two cytogenetic subtypes, one with gain of $3 \mathrm{q}$ and the other with loss of $7 \mathrm{q}$. Haematologica. 2001; 86:71-77.

50. Andersen CL, Gruszka-Westwood A, Østergaard M, Koch J, Jacobsen E, Kjeldsen E, Nielsen B. A narrow deletion of $7 \mathrm{q}$ is common to HCL, and SMZL, but not CLL. Eur J Haematol. 2004; 72:390-402. https://doi. org/10.1111/j.1600-0609.2004.00243.x.

51. Vega F, Cho-Vega JH, Lennon PA, Luthra MG, Bailey J, Breeden M, Jones D, Medeiros LJ, Luthra R. Splenic marginal zone lymphomas are characterized by loss of interstitial regions of chromosome 7q, 7q31.32 and 7q36.2 that include the protection of telomere 1 (POT1) and sonic hedgehog (SHH) genes. Br J Haematol. 2008; 142:216-26. https://doi.org/10.1111/j.1365-2141.2008.07176.x.

52. Novara F, Arcaini L, Merli M, Passamonti F, Zibellini S, Rizzi S, Rattotti S, Rumi E, Pascutto C, Vetro A, Astori $\mathrm{C}$, Boveri E, Lucioni M, et al. High-resolution genomewide array comparative genomic hybridization in splenic marginal zone B-cell lymphoma. Hum Pathol. 2009; 40:1628-37. https://doi.org/10.1016/j.humpath.2009.01.025.

53. Rinaldi A, Mian M, Chigrinova E, Arcaini L, Bhagat G, Novak U, Rancoita PM, De Campos CP, Forconi F, Gascoyne RD, Facchetti F, Ponzoni M, Govi S, et al. Genome-wide DNA profiling of marginal zone lymphomas identifies subtype-specific lesions with an impact on the clinical outcome. Blood. 2011; 117:1595-604. https://doi. org/10.1182/blood-2010-01-264275.

54. Chambwe N, Kormaksson M, Geng H, De S, Michor F, Johnson NA, Morin RD, Scott DW, Godley LA, Gascoyne RD, Melnick A, Campagne F, Shaknovich R. Variability in DNA methylation defines novel epigenetic subgroups of DLBCL associated with different clinical outcomes. Blood. 2014; 123:1699-708. https://doi.org/10.1182/ blood-2013-07-509885.

55. Upchurch GM, Haney SL, Opavsky R. Aberrant Promoter Hypomethylation in CLL: Does It Matter for Disease Development? Front Oncol. 2016; 6:182. https://doi. org/10.3389/fonc.2016.00182.

56. Frazzi R, Zanetti E, Pistoni M, Tamagnini I, Valli R, Braglia L, Merli F. Methylation changes of SIRT1, KLF4, DAPK1 and SPG20 in B-lymphocytes derived from follicular and diffuse large B-cell lymphoma. Leuk Res. 2017; 57:89-96. https://doi.org/10.1016/j.leukres.2017.02.012.

57. Zhang YW, Zhang J, Li J, Zhu JF, Yang YL, Zhou LL, $\mathrm{Hu}$ ZL, Zhang F. Methylation contributes to imbalance of PRDM1 $\alpha /$ PRDM1b $\beta$ expression in diffuse large B-cell lymphoma. Leuk Lymphoma. 2015; 56:2429-38. https:// doi.org/10.3109/10428194.2014.994181.

58. Vasilatou D, Sioulas AD, Pappa V, Papanikolaou IS, Triantafyllou K, Dimitriadis GD, Papageorgiou SG. The role of miRNAs and epigenetic mechanisms in primary gastric mucosa-associated lymphoid tissue lymphoma. Future Oncol. 2016; 12:1587-93. https://doi.org/10.2217/ fon-2016-0038.

59. Arribas AJ, Rinaldi A, Mensah AA, Kwee I, Cascione L, Robles EF, Martinez-Climent JA, Oscier D, Arcaini L, Baldini L, Marasca R, Thieblemont C, Briere J, et al. DNA methylation profiling identifies two splenic marginal zone lymphoma subgroups with different clinical and genetic features. Blood. 2015; 125:1922-31. https://doi. org/10.1182/blood-2014-08-596247.

60. Di Leva G, Garofalo M, Croce CM. MicroRNAs in cancer. Annu Rev Pathol. 2014; 9:287-314. https://doi.org/10.1146/ annurev-pathol-012513-104715.

61. Calin GA, Croce CM. MicroRNA signatures in human cancers. Nat Rev Cancer. 2006; 6:857-66. https:/doi. org/10.1038/nrc1997.

62. Musilova K, Mraz M. MicroRNAs in B-cell lymphomas: how a complex biology gets more complex. Leukemia. 2015; 29:1004-17. https://doi.org/10.1038/leu.2014.351.

63. Calin GA, Dumitru CD, Shimizu M, Bichi R, Zupo S, Noch E, Aldler H, Rattan S, Keating M, Rai K, Rassenti L, Kipps T, Negrini M, et al. Frequent deletions and down-regulation of micro- RNA genes miR15 and miR16 at 13q14 in chronic lymphocytic leukemia. Proc Natl Acad Sci USA. 2002; 99:15524-29. https://doi.org/10.1073/pnas.242606799.

64. Roehle A, Hoefig KP, Repsilber D, Thorns C, Ziepert M, Wesche KO, Thiere M, Loeffler M, Klapper W, Pfreundschuh M, Matolcsy A, Bernd HW, Reiniger L, et al. MicroRNA signatures characterize diffuse large B-cell lymphomas and follicular lymphomas. Br J Haematol. 2008; 142:732-44. https://doi. org/10.1111/j.1365-2141.2008.07237.x.

65. Balatti V, Pekarky Y, Croce CM. Role of microRNA in chronic lymphocytic leukemia onset and progression. J Hematol Oncol. 2015; 8:12. https://doi.org/10.1186/ s13045-015-0112-x.

66. Thorns C, Kuba J, Bernard V, Senft A, Szymczak S, Feller AC, Bernd HW. Deregulation of a distinct set of microRNAs is associated with transformation of gastritis into MALT lymphoma. Virchows Arch. 2012; 460:371-77. https://doi.org/10.1007/s00428-012-1215-1.

67. Zhang X, Zhao X, Fiskus W, Lin J, Lwin T, Rao R, Zhang Y, Chan JC, Fu K, Marquez VE, Chen-Kiang S, Moscinski LC, Seto E, et al. Coordinated silencing of MYC-mediated 
miR-29 by HDAC3 and EZH2 as a therapeutic target of histone modification in aggressive B-Cell lymphomas. Cancer Cell. 2012; 22:506-23. https://doi.org/10.1016/j. ccr.2012.09.003.

68. Jardin F, Figeac M. MicroRNAs in lymphoma, from diagnosis to targeted therapy. Curr Opin Oncol. 2013; 25:480-86. https://doi.org/10.1097/ CCO.0b013e328363def2.

69. Wang W, Corrigan-Cummins M, Hudson J, Maric I, Simakova O, Neelapu SS, Kwak LW, Janik JE, Gause B, Jaffe ES, Calvo KR. MicroRNA profiling of follicular lymphoma identifies microRNAs related to cell proliferation and tumor response. Haematologica. 2012; 97:586-94. https://doi.org/10.3324/haematol.2011.048132.

70. Deng S, Calin GA, Croce CM, Coukos G, Zhang L. Mechanisms of microRNA deregulation in human cancer. Cell Cycle. 2008; 7:2643-46. https://doi.org/10.4161/ cc.7.17.6597.

71. Coffre M, Koralov SB. miRNAs in B Cell Development and Lymphomagenesis. Trends Mol Med. 2017; 23:721-36. https://doi.org/10.1016/j.molmed.2017.06.001.

72. Kozloski GA, Lossos IS. LymphomiRs: microRNAs with regulatory roles in lymphomas. Curr Opin Hematol. 2015; 22:362-68.

73. Di Lisio L, Sánchez-Beato M, Gómez-López G, Rodríguez ME, Montes-Moreno S, Mollejo M, Menárguez J, Martínez MA, Alves FJ, Pisano DG, Piris MA, Martínez N. MicroRNA signatures in B-cell lymphomas. Blood Cancer J. 2012; 2:e57. https://doi.org/10.1038/bcj.2012.1.

74. Lawrie CH. MicroRNAs and lymphomagenesis: a functional review. Br J Haematol. 2013; 160:571-81. https://doi.org/10.1111/bjh.12157.

75. Ruiz-Ballesteros E, Mollejo M, Mateo M, Algara P, Martínez P, Piris MA. MicroRNA losses in the frequently deleted region of 7q in SMZL. Leukemia. 2007; 21:254749. https://doi.org/10.1038/sj.leu.2404853.

76. Watkins AJ, Hamoudi RA, Zeng N, Yan Q, Huang Y, Liu H, Zhang J, Braggio E, Fonseca R, de Leval L, Isaacson PG, Wotherspoon A, McPhail ED, et al. An integrated genomic and expression analysis of $7 \mathrm{q}$ deletion in splenic marginal zone lymphoma. PLoS One. 2012; 7:e44997. https://doi. org/10.1371/journal.pone.0044997.

77. Bouteloup M, Verney A, Rachinel N, Callet-Bauchu E, Ffrench M, Coiffier B, Magaud JP, Berger F, Salles GA, Traverse-Glehen A. MicroRNA expression profile in splenic marginal zone lymphoma. Br J Haematol. 2012; 156:27981. https://doi.org/10.1111/j.1365-2141.2011.08848.x.

78. Arribas AJ, Gómez-Abad C, Sánchez-Beato M, Martinez N, Dilisio L, Casado F, Cruz MA, Algara P, Piris MA, Mollejo M. Splenic marginal zone lymphoma: comprehensive analysis of gene expression and miRNA profiling. Mod Pathol. 2013; 26:889-901. https://doi.org/10.1038/ modpathol.2012.220.
79. Peveling-Oberhag J, Crisman G, Schmidt A, Döring C, Lucioni M, Arcaini L, Rattotti S, Hartmann S, Piiper A, Hofmann WP, Paulli M, Küppers R, Zeuzem S, Hansmann ML. Dysregulation of global microRNA expression in splenic marginal zone lymphoma and influence of chronic hepatitis C virus infection. Leukemia. 2012; 26:1654-62. https://doi.org/10.1038/leu.2012.29.

80. Zhou K, Yi S, Yu Z, Li Z, Wang Y, Zou D, Qi J, Zhao Y, Qiu L. MicroRNA-223 expression is uniformly down-regulated in B cell lymphoproliferative disorders and is associated with poor survival in patients with chronic lymphocytic leukemia. Leuk Lymphoma. 2012; 53:1155-61. https://doi. org/10.3109/10428194.2011.642303.

81. Munari E, Rinaldi M, Ambrosetti A, Bonifacio M, Bonalumi A, Chilosi M, Zamò A. Absence of TCL1A expression is a useful diagnostic feature in splenic marginal zone lymphoma. Virchows Arch. 2012; 461:677-85. https:// doi.org/10.1007/s00428-012-1322-Z.

82. Chang TC, Yu D, Lee YS, Wentzel EA, Arking DE, West KM, Dang CV, Thomas-Tikhonenko A, Mendell JT. Widespread microRNA repression by Myc contributes to tumorigenesis. Nat Genet. 2008; 40:43-50. https://doi. org/10.1038/ng.2007.30.

83. Zhao JJ, Lin J, Lwin T, Yang H, Guo J, Kong W, Dessureault S, Moscinski LC, Rezania D, Dalton WS, Sotomayor E, Tao J, Cheng JQ. microRNA expression profile and identification of miR-29 as a prognostic marker and pathogenetic factor by targeting CDK6 in mantle cell lymphoma. Blood. 2010; 115:2630-39. https://doi. org/10.1182/blood-2009-09-243147.

84. Xu L, Xu Y, Jing Z, Wang X, Zha X, Zeng C, Chen S, Yang L, Luo G, Li B, Li Y. Altered expression pattern of miR-29a, miR-29b and the target genes in myeloid leukemia. Exp Hematol Oncol. 2014; 3:17. https://doi. org/10.1186/2162-3619-3-17.

85. Oliveira LH, Schiavinato JL, Fráguas MS, Lucena-Araujo AR, Haddad R, Araújo AG, Dalmazzo LF, Rego EM, Covas DT, Zago MA, Panepucci RA. Potential roles of microRNA-29a in the molecular pathophysiology of T-cell acute lymphoblastic leukemia. Cancer Sci. 2015; 106:126477. https://doi.org/10.1111/cas.12766.

86. Qi Y, Huang Y, Pang L, Gu W, Wang N, Hu J, Cui X, Zhang J, Zhao J, Liu C, Zhang W, Zou H, Li F. Prognostic value of the MicroRNA-29 family in multiple human cancers: A meta-analysis and systematic review. Clin Exp Pharmacol Physiol. 2017; 44:441-54. https://doi. org/10.1111/1440-1681.12726.

87. Wang Y, Zhang X, Li H, Yu J, Ren X. The role of miRNA29 family in cancer. Eur J Cell Biol. 2013; 92:123-28. https://doi.org/10.1016/j.ejcb.2012.11.004.

88. Pekarsky Y, Santanam U, Cimmino A, Palamarchuk A, Efanov A, Maximov V, Volinia S, Alder H, Liu CG, Rassenti L, Calin GA, Hagan JP, Kipps T, Croce CM. Tcl1 expression in chronic lymphocytic leukemia is regulated 
by miR-29 and miR-181. Cancer Res. 2006; 66:11590-93. https://doi.org/10.1158/0008-5472.CAN-06-3613.

89. Gao Y, Feng B, Han S, Lu L, Chen Y, Chu X, Wang R, Chen L. MicroRNA-129 in Human Cancers: from Tumorigenesis to Clinical Treatment. Cell Physiol Biochem. 2016; 39:2186-202. https://doi.org/10.1159/000447913.

90. Karaayvaz M, Zhai H, Ju J. miR-129 promotes apoptosis and enhances chemosensitivity to 5-fluorouracil in colorectal cancer. Cell Death Dis. 2013; 4:e659. https://doi. org/10.1038/cddis.2013.193.

91. Zhu W, Liu X, He J, Chen D, Hunag Y, Zhang YK. Overexpression of members of the microRNA-183 family is a risk factor for lung cancer: a case control study. BMC Cancer. 2011; 11:393. https://doi. org/10.1186/1471-2407-11-393.

92. Lin Q, Mao W, Shu Y, Lin F, Liu S, Shen H, Gao W, Li S, Shen D. A cluster of specified microRNAs in peripheral blood as biomarkers for metastatic non-smallcell lung cancer by stem-loop RT-PCR. J Cancer Res Clin Oncol. 2012; 138:85-93. https://doi.org/10.1007/ s00432-011-1068-z.

93. Damm F, Markus B, Thol F, Heuser M, Ganser A, Krauter J. Genetic changes of miR-182 G106A: rather a polymorphism than a somatic mutation. Ann Hematol. 2011; 90:1107-09. https://doi.org/10.1007/s00277-010-1131-x.

94. Ma Y, Liang AJ, Fan YP, Huang YR, Zhao XM, Sun Y, Chen XF. Dysregulation and functional roles of miR-18396-182 cluster in cancer cell proliferation, invasion and metastasis. Oncotarget. 2016; 7:42805-42825. https://doi. org/10.18632/oncotarget.8715.

95. Di Lisio L, Gómez-López G, Sánchez-Beato M, GómezAbad C, Rodríguez ME, Villuendas R, Ferreira BI, Carro A, Rico D, Mollejo M, Martínez MA, Menárguez J, DíazAlderete A, et al. Mantle cell lymphoma: transcriptional regulation by microRNAs. Leukemia. 2010; 24:1335-42. https://doi.org/10.1038/leu.2010.91.

96. Blume CJ, Hotz-Wagenblatt A, Hüllein J, Sellner L, Jethwa A, Stolz T, Slabicki M, Lee K, Sharathchandra A, Benner A, Dietrich S, Oakes CC, Dreger P, et al. p53-dependent noncoding RNA networks in chronic lymphocytic leukemia. Leukemia. 2015; 29:2015-23. https://doi.org/10.1038/ leu.2015.119.

97. Dambal S, Shah M, Mihelich B, Nonn L. The microRNA-183 cluster: the family that plays together stays together. Nucleic Acids Res. 2015; 43:7173-88. https://doi. org/10.1093/nar/gkv703.

98. Guttilla IK, White BA. Coordinate regulation of FOXO1 by miR-27a, miR-96, and miR-182 in breast cancer cells. J Biol Chem. 2009; 284:23204-16. https://doi.org/10.1074/ jbc.M109.031427.

99. Li J, Fu H, Xu C, Tie Y, Xing R, Zhu J, Qin Y, Sun Z, Zheng X. miR-183 inhibits TGF- $\beta 1$-induced apoptosis by downregulation of PDCD4 expression in human hepatocellular carcinoma cells. BMC Cancer. 2010; 10:354. https://doi.org/10.1186/1471-2407-10-354.
100. Sirotkin AV, Lauková M, Ovcharenko D, Brenaut P, Mlynček M. Identification of microRNAs controlling human ovarian cell proliferation and apoptosis. J Cell Physiol. 2010; 223:49-56.

101. Stittrich AB, Haftmann C, Sgouroudis E, Kühl AA, Hegazy AN, Panse I, Riedel R, Flossdorf M, Dong J, Fuhrmann F, Heinz GA, Fang Z, Li N, et al. The microRNA miR-182 is induced by IL-2 and promotes clonal expansion of activated helper T lymphocytes. Nat Immunol. 2010; 11:1057-62. https://doi.org/10.1038/ni.1945.

102. Bai AH, Milde T, Remke M, Rolli CG, Hielscher T, Cho YJ, Kool M, Northcott PA, Jugold M, Bazhin AV, Eichmüller SB, Kulozik AE, Pscherer A, et al. MicroRNA-182 promotes leptomeningeal spread of non-sonic hedgehogmedulloblastoma. Acta Neuropathol. 2012; 123:529-38. https://doi.org/10.1007/s00401-011-0924-x.

103. Fendler A, Jung M, Stephan C, Erbersdobler A, Jung K, Yousef GM. The antiapoptotic function of miR-96 in prostate cancer by inhibition of FOXO1. PLoS One. 2013; 8:e80807. https://doi.org/10.1371/journal.pone.0080807.

104. Guo Y, Liao Y, Jia C, Ren J, Wang J, Li T. MicroRNA-182 promotes tumor cell growth by targeting transcription elongation factor A-like 7 in endometrial carcinoma. Cell Physiol Biochem. 2013; 32:581-90. https://doi. org/10.1159/000354462.

105. Wang YQ, Guo RD, Guo RM, Sheng W, Yin LR. MicroRNA-182 promotes cell growth, invasion, and chemoresistance by targeting programmed cell death 4 (PDCD4) in human ovarian carcinomas. J Cell Biochem. 2013; 114:1464-73. https://doi.org/10.1002/jcb.24488.

106. Zhang Z, Li S, Cheng SY. The miR-183- 96- 182 cluster promotes tumorigenesis in a mouse model of medulloblastoma. J Biomed Res. 2013; 27:486.

107. Cheng Y, Xiang G, Meng Y, Dong R. MiRNA-183-5p promotes cell proliferation and inhibits apoptosis in human breast cancer by targeting the PDCD4. Reprod Biol. 2016; 16:225-33. https://doi.org/10.1016/j.repbio.2016.07.002.

108. Wang X, Zuo D, Yuan Y, Yang X, Hong Z, Zhang R. MicroRNA-183 promotes cell proliferation via regulating programmed cell death 6 in pediatric acute myeloid leukemia. J Cancer Res Clin Oncol. 2017; 143:169-80. https://doi.org/10.1007/s00432-016-2277-2.

109. Kim CG, Lee H, Gupta N, Ramachandran S, Kaushik I, Srivastava S, Kim SH, Srivastava SK. Role of Forkhead Box Class O proteins in cancer progression and metastasis. Semin Cancer Biol. 2018; 50:142-151. https://doi.org/10.1016/j. semcancer.2017.07.007.

110. Luo LJ, Wang DD, Wang J, Yang F, Tang JH. Diverse roles of miR-335 in development and progression of cancers. Tumour Biol. 2016; 37:15399-410. https://doi.org/10.1007/ s13277-016-5385-3.

111. Scarola M, Schoeftner S, Schneider C, Benetti R. miR-335 directly targets $\mathrm{Rb} 1$ (pRb/p105) in a proximal connection to p53-dependent stress response. Cancer Res. 2010; 70:692533. https://doi.org/10.1158/0008-5472.CAN-10-0141. 
112. Wang H, Li M, Zhang R, Wang Y, Zang W, Ma Y, Zhao G, Zhang G. Effect of miR-335 upregulation on the apoptosis and invasion of lung cancer cell A549 and H1299. Tumour Biol. 2013; 34:3101-09. https://doi.org/10.1007/ s13277-013-0878-9.

113. Wang K, Chen X, Zhan Y, Jiang W, Liu X, Wang X, Wu B. miR-335 inhibits the proliferation and invasion of clear cell renal cell carcinoma cells through direct suppression of BCL-W. Tumour Biol. 2015; 36:6875-82. https://doi. org/10.1007/s13277-015-3382-6.

114. Zou W, McDaneld L, Smith LM. Caveolin-1 haploinsufficiency leads to partial transformation of human breast epithelial cells. Anticancer Res. 2003; 23:4581-86.

115. Drusco A, Pekarsky Y, Costinean S, Antenucci A, Conti L, Volinia S, Aqeilan RI, Huebner K, Zanesi N. Common fragile site tumor suppressor genes and corresponding mouse models of cancer. J Biomed Biotechnol. 2011; 2011:984505. https://doi.org/10.1155/2011/984505.

116. Shukla A, Cutucache CE, Sutton GL, Pitner MA, Rai K, Rai S, Opavsky R, Swanson PC, Joshi SS. Absence of caveolin-1 leads to delayed development of chronic lymphocytic leukemia in E $\mu$-TCL1 mouse model 116. Exp Hematol. 2016; 44:30-7.e1. https://doi.org/10.1016/j. exphem.2015.09.005.

117. Patten CL, Cutucache CE. Murine Models of Splenic Marginal Zone Lymphoma: A Role for Cav1? Front Oncol. 2016; 6:258. https://doi.org/10.3389/fonc.2016.00258.

118. Troppan K, Wenzl K, Pichler M, Pursche B, Schwarzenbacher D, Feichtinger J, Thallinger GG, Beham-Schmid C, Neumeister P, Deutsch A. miR-199a and miR-497 are associated with better overall survival due to increased chemosensitivity in diffuse large B-cell lymphoma patients. Int J Mol Sci. 2015; 16:18077-95. https://doi.org/10.3390/ijms160818077.

119. Chen R, Alvero AB, Silasi DA, Kelly MG, Fest S, Visintin I, Leiser A, Schwartz PE, Rutherford T, Mor G. Regulation of IKKbeta by miR-199a affects NF-kappaB activity in ovarian cancer cells. Oncogene. 2008; 27:4712-23. https:// doi.org/10.1038/onc.2008.112.

120. Lawrie CH, Chi J, Taylor S, Tramonti D, Ballabio E, Palazzo S, Saunders NJ, Pezzella F, Boultwood J, Wainscoat JS, Hatton CS. Expression of microRNAs in diffuse large B cell lymphoma is associated with immunophenotype, survival and transformation from follicular lymphoma. J Cell Mol Med. 2009; 13:1248-60. https://doi. org/10.1111/j.1582-4934.2008.00628.x.

121. Yin G, Chen R, Alvero AB, Fu HH, Holmberg J, Glackin C, Rutherford T, Mor G. TWISTing stemness, inflammation and proliferation of epithelial ovarian cancer cells through MIR199A2/214. Oncogene. 2010; 29:3545-53. https://doi. org/10.1038/onc.2010.111.

122. Kim S, Lee UJ, Kim MN, Lee EJ, Kim JY, Lee MY, Choung S, Kim YJ, Choi YC. MicroRNA miR-199a* regulates the MET proto-oncogene and the downstream extracellular signal-regulated kinase 2 (ERK2). J Biol Chem. 2008; 283:18158-66. https://doi.org/10.1074/jbc.M800186200.

123. Zheng Z, Li X, Zhu Y, Gu W, Xie X, Jiang J. Prognostic significance of MiRNA in patients with diffuse large B-Cell lymphoma: a meta-analysis. Cell Physiol Biochem. 2016; 39:1891-904. https://doi.org/10.1159/000447887.

124. Lino Cardenas CL, Henaoui IS, Courcot E, Roderburg C, Cauffiez C, Aubert S, Copin MC, Wallaert B, Glowacki F, Dewaeles E, Milosevic J, Maurizio J, Tedrow J, et al. miR-199a-5p Is upregulated during fibrogenic response to tissue injury and mediates TGFbeta-induced lung fibroblast activation by targeting caveolin-1. PLoS Genet. 2013; 9:e1003291. https://doi.org/10.1371/journal.pgen.1003291.

125. Aranda JF, Canfrán-Duque A, Goedeke L, Suárez Y, Fernández-Hernando C. The miR-199-dynamin regulatory axis controls receptor-mediated endocytosis. J Cell Sci. 2015; 128:3197-209. https://doi.org/10.1242/jcs.165233.

126. Gilling CE, Mittal AK, Chaturvedi NK, Iqbal J, Aoun P, Bierman PJ, Bociek RG, Weisenburger DD, Joshi SS. Lymph node-induced immune tolerance in chronic lymphocytic leukaemia: a role for caveolin-1. Br J Haematol. 2012; 158:216-31. https://doi. org/10.1111/j.1365-2141.2012.09148.x.

127. Gilling CE, Mittal AK, Joshi SS. Immune synapse malformation: role for CAV1 and PAK1. FASEB J. 2012; 26:522.7.

128. Tse EY, Ko FC, Tung EK, Chan LK, Lee TK, Ngan ES, Man K, Wong AS, Ng IO, Yam JW, Man K, Wong A, Ng I, et al. Caveolin-1 overexpression is associated with hepatocellular carcinoma tumourigenesis and metastasis. J Pathol. 2012; 226:645-53. https://doi.org/10.1002/path.3957.

129. Herek TA, Shew TD, Spurgin HN, Cutucache CE. Conserved molecular underpinnings and characterization of a role for caveolin-1 in the tumor microenvironment of mature T-cell lymphomas. PLoS One. 2015; 10:e142682. https://doi.org/10.1371/journal.pone.0142682.

130. Vangapandu HV, Chen H, Wierda WG, Keating MJ, Korkut A, Gandhi V. Proteomics profiling identifies induction of caveolin-1 in chronic lymphocytic leukemia cells by bone marrow stromal cells. Leuk Lymphoma. 2018; 59:1427-1438.

131. Yang L, Wei QM, Zhang XW, Sheng Q, Yan XT. MiR-376a promotion of proliferation and metastases in ovarian cancer: potential role as a biomarker. Life Sci. 2017; 173:62-67. https://doi.org/10.1016/j.lfs.2016.12.007.

132. An N, Luo X, Zhang M, Yu R. MicroRNA-376b promotes breast cancer metastasis by targeting Hoxd10 directly. Exp Ther Med. 2017; 13:79-84. https://doi.org/10.3892/ etm.2016.3942.

133. Huang Q, Wang C, Hou Z, Wang G, Lv J, Wang H, Yang J, Zhang Z, Zhang H. Serum microRNA-376 family as diagnostic and prognostic markers in human gliomas. Cancer Biomark. 2017; 19:137-44. https://doi.org/10.3233/ CBM-160146. 
134. Zehavi L, Avraham R, Barzilai A, Bar-Ilan D, Navon R, Sidi Y, Avni D, Leibowitz-Amit R. Silencing of a large microRNA cluster on human chromosome $14 \mathrm{q} 32$ in melanoma: biological effects of mir-376a and mir-376c on insulin growth factor 1 receptor. Mol Cancer. 2012; 11:44. https://doi.org/10.1186/1476-4598-11-44.

135. Formosa A, Markert EK, Lena AM, Italiano D, FinazziAgro' E, Levine AJ, Bernardini S, Garabadgiu AV, Melino G, Candi E. MicroRNAs, miR-154, miR-299-5p, miR-376a, miR-376c, miR-377, miR-381, miR-487b, miR-485-3p, miR-495 and miR-654-3p, mapped to the 14q32.31 locus, regulate proliferation, apoptosis, migration and invasion in metastatic prostate cancer cells. Oncogene. 2014; 33:517382. https://doi.org/10.1038/onc.2013.451.

136. Tekirdag KA, Akkoc Y, Kosar A, Gozuacik D. MIR376 family and cancer. Histol Histopathol. 2016; 31:841-55.

137. Guo T, Xu L, Che X, Zhang S, Li C, Wang J, Gong J, Ma R, Fan Y, Hou K, Zhou H, Hu X, Liu Y, Qu X. Formation of the IGF1R/CAV1/SRC tri-complex antagonizes TRAILinduced apoptosis in gastric cancer cells. Cell Biol Int. 2017; 41:749-60. https://doi.org/10.1002/cbin.10775.

138. Gascoyne DM, Banham AH. The significance of FOXP1 in diffuse large B-cell lymphoma. Leuk Lymphoma. 2017; 58:1037-51. https://doi.org/10.1080/10428194.2016.1228932.

139. Hezaveh K, Kloetgen A, Bernhart SH, Mahapatra KD, Lenze D, Richter J, Haake A, Bergmann AK, Brors B, Burkhardt B, Claviez A, Drexler HG, Eils R, et al, and ICGC MMMLSeq Project. Alterations of microRNA and microRNAregulated messenger RNA expression in germinal center B-cell lymphomas determined by integrative sequencing analysis. Haematologica. 2016; 101:1380-89. https://doi. org/10.3324/haematol.2016.143891.
140. Chen CF, He X, Arslan AD, Mo YY, Reinhold WC, Pommier Y, Beck WT. Novel regulation of nuclear factor-YB by miR-485-3p affects the expression of DNA topoisomerase II $\alpha$ and drug responsiveness. Mol Pharmacol. 2011; 79:735-41. https://doi.org/10.1124/mol.110.069633.

141. Lucotti S, Rainaldi G, Evangelista M, Rizzo M. Fludarabine treatment favors the retention of miR-485-3p by prostate cancer cells: implications for survival. Mol Cancer. 2013; 12:52. https://doi.org/10.1186/1476-4598-12-52.

142. Anaya-Ruiz M, Bandala C, Perez-Santos JL. miR-485 acts as a tumor suppressor by inhibiting cell growth and migration in breast carcinoma T47D cells. Asian Pac J Cancer Prev. 2013; 14:3757-60. https://doi.org/10.7314/ APJCP.2013.14.6.3757.

143. Lou C, Xiao M, Cheng S, Lu X, Jia S, Ren Y, Li Z. MiR-485-3p and miR-485-5p suppress breast cancer cell metastasis by inhibiting PGC-1 $\alpha$ expression. Cell Death Dis. 2016; 7:e2159. https://doi.org/10.1038/cddis.2016.27.

144. Kim TH, Kim YK, Kwon Y, Heo JH, Kang H, Kim G, An HJ. Deregulation of miR-519a, 153, and 485-5p and its clinicopathological relevance in ovarian epithelial tumours. Histopathology. 2010; 57:734-43. https://doi. org/10.1111/j.1365-2559.2010.03686.x.

145. Wang ZQ, Zhang MY, Deng ML, Weng NQ, Wang HY, $\mathrm{Wu} \mathrm{SX}$. Low serum level of miR-485-3p predicts poor survival in patients with glioblastoma. PLoS One. 2017; 12:e184969. https://doi.org/10.1371/journal.pone.0184969.

146. He N, Zheng H, Li P, Zhao Y, Zhang W, Song F, Chen K. miR-485-5p binding site SNP rs8752 in HPGD gene is associated with breast cancer risk. PLoS One. 2014; 9:e102093. https://doi.org/10.1371/journal.pone.0102093. 